\title{
The main plant mineral nutrition balance on using ecological fertilizers
}

\author{
Auksė Burakova, \\ Eugenija Bakšienè, \\ Almantas Ražukas \\ Lithuanian Research Centre \\ for Agriculture and Forestry, \\ Voke Branch, 2 Žalioji Sq., \\ 02232 Vilnius, Lithuania \\ Email:aukse.burakova@lammc.lt; \\ eugenija.baksiene@lammc.lt
}

The experiments were performed in stationary cylindrical lysimeters, which were filled with soil typical of the Eastern Lithuanian region: sandy loam and loamy sand soil (Haplic Luvisol). In the experiment, the main aim was to investigate the balance of nitrogen $(\mathrm{N})$, phosphorus (P) and potassium (K) in the sandy loam and loamy sand Haplic Luvisol and to evaluate their effectiveness and suitability for the light texture soil and agricultural crop harvest in organic agriculture. It was found that, in general, during the three years of the experiment, the balance of $\mathrm{N}$ in the sandy loam and loamy sand soil was negative, but fertilization with organic sapropel showed the positive results: less $\mathrm{N}$ leaching losses content, compared to other organic-organic fertilizers. Fertilization with cattle manure did not ensure the $P$ positive element balance, in both types of soils, due to a small amount of $\mathrm{P}$ in the fertilizer and a high accumulation in the yield. The amount of potassium added each year with NPK fertilizer ensured a positive element balance only in the sandy loam soil.

Keywords: crop yield, leaching loss, NPK balance, organic fertilizers

\section{INTRODUCTION}

Organic agriculture based on natural processes in the soil, and the nutrition of cultivated plants relates only to natural plant nutrients. According to the principles of organic agriculture, fertilization requires soil rather than plants. In an organic farm, soil fertility is particularly essential. Without the use of synthetic mineral fertilizers, yields and the success of economic activity are directly dependent on soil fertility from vitality to a level of cultivation (Ahlvik et al., 2014; Timmusk et al., 2017; Timsina, 2018).

The importance of nutrient balance has overgrown from the historical side to make decisions about the history and functioning of the agroecosystem possibilities. In agriculture, all factors are observed and combined from past information to the current prediction process of nutrient cycle, which helps to create soil management practices. Sustainability of a production system implies optimum yields that can be maintained with a minimum or an acceptable environmental consequence through an organic fertilizer (Fess, Benedito, 2018). Those three NPK elements monitored and analysed not long ago have become a starting point for a study of nutrients balance in agriculture. These small-scale tillage system studies have developed into common world practice. In general, the agro-ecosystem is analysed as a whole, 
combining all land uses in that region. Still, some of the studies were dedicated to only one crop or crop rotation (El-Ramady et al., 2014; Jones et al., 2017).

Each of those three nutrients has a specific importance. Nitrogen is the most critical element for plant harvest growing because it is often deficient and yields obvious benefits. $\mathrm{N}$ fertilization generally increases yield. Nitrogen is continually cycled among plants, soil organisms, soil organic matter, water and the atmosphere. Scientists conclude that organic farming produces lower or similar levels of nitrate leaching compared to integrated or conventional agriculture. The greatest risk is faced when $\mathrm{N}$ released from organic fertilizers does not coincide with the level of uptake by crops or when $\mathrm{N}$ fertilization rates start to exceed those calculated (based on known yields) (Doltra, Olesen, 2013; Delin, Stenberg, 2014; Duran et al., 2016). Nitrogen (N) indicators are key for characterizing farm performance, because of the role of $\mathrm{N}$ in food production and environmental sustainability. A systematic monitoring of $\mathrm{N}$ balance at the farm level could contribute to understanding differences in $\mathrm{N}$ management and impacts among farms.

Nowadays, phosphorus (P) is an element of the main interest. It is associated with limited or abundant global soil reserves. Currently, $\mathrm{P}$ release into the biosphere is triple times higher in connection with a higher rate of used fertilizers and growth of livestock husbandry production in the world. In some agricultural soils, the accumulated $\mathrm{P}$ is subsequently washed into deeper layers and acts eutrophically. Phosphorus is less mobile in soil, and leaching loss is lower as compared to other nutrients. Besides, phosphate is extraordinarily reactive and binds strongly with iron, calcium, and other elements present in soils. Phosphorus losses vary from one event to another (Islam et al., 2015; Khan et al., 2017).

Many researchers confirm the importance of fertilizer efficiency in the soils with a very light texture, which prevents nutrient leaching from the arable soil layer to deeper layers (Diacono, Motemourro, 2015; Belén et al., 2016).

Scientists found that due to the excessive manure use in agricultural lands with the main elements as $\mathrm{N}$ and $\mathrm{P}$, leaching contributes to the increased $\mathrm{NO}_{3}{ }^{-}$concentrations and eutrophication of groundwater process (Li et al., 2018).
Although potassium $(\mathrm{K})$ plays a significant role in the plant growth process, it comes as a forgotten element, and it is considered less critical than $\mathrm{N}$ or P. Potassium reserves in the world seem to be adequate for hundreds of years. Still, the productivity of soils in the future will increasingly depend on its efficient use (Zörb et al., 2014).

Soils in south-eastern Lithuania are not the most suitable for the organic farming, but the incorporation of organic fertilizers should create the conditions that prevent losses of sustainability of the primary nutrients in the soil and optimize the yield of crops without elements losses. Calculations of plant nutrient balance are the optimal way to help farmers to carry out agricultural work purposefully as well as monitor the losses of nutrients through harvest and leaching.

The research aimed to evaluate the balance of $\mathrm{N}, \mathrm{P}, \mathrm{K}$, and the change tendency of biogenic elements with the use of organic fertilizers and to determine their efficiency and suitability on the light texture soil and agricultural crop harvest in organic agriculture.

\section{MATERIALS AND METHODS}

\section{Experiment location}

The experiment was set up at the Voke Branch of the Lithuanian Research Centre for Agriculture and Forestry (2016-2018). The research was carried out in 24 plots of stationary concrete cylindrical lysimeters (1.35 $\mathrm{m}$ depth). They were filled with the Haplic Luvisol (WRB, 2015) soil from two sides: 12 plots for one side (each surface area $1.75 \mathrm{~m}^{2}$ ) were filled with sandy loam and 12 plots from another side (each covering $1.75 \mathrm{~m}^{2}$ ) with loamy sand, typical of the Eastern Lithuanian region. The experiment treatment (with three replications) was as follows: 1) control (without fertilizers), 2) NPK fertilizers (Provita, phosphorite powder, potassium magnesia), 3) $40 \mathrm{t} \mathrm{ha}^{-1}$ sapropel and 4) $60 \mathrm{t} \mathrm{ha}^{-1}$ manure. In the experiment, the following fertilizers were used: manure - cattle manure with straw, sapropel - organic (from Kereplis Lake, Trakai District). The rates for sapropel and manure fertilizer are presented in natural matter and the amount of incorporated elements is calculated in dry matter. In dry matter, the rate of fertilizers was as follows: sapropel $-8.52 \mathrm{t}$ and cattle manure $-9 \mathrm{t}$. 
NPK fertilizers were added before seeding: the summer barley at the rate $\mathrm{N}_{50} \mathrm{P}_{50} \mathrm{~K}_{50}$, the potato tubers $\mathrm{N}_{60} \mathrm{P}_{60} \mathrm{~K}_{60}$ and the peas in the growing year $\mathrm{N}_{0} \mathrm{P}_{50} \mathrm{~K}_{50}$ (the roots of the peas fixing nitrogen from the air, it is recommended to take care of phosphorus $(\mathrm{P})$ and potassium $(\mathrm{K})$ insertion for optimal bacterial activity).

Sapropel and manure fertilizers were inserted in the first year of the experiment, and the effect on crop yield, soil chemical properties and biogenic element circulation was monitored next year. NPK ecological fertilizer was inserted every year before seeding.

Ekoagros certified ecological fertilizers such as Provita, phosphorite powder and potassium magnesia (Patentkali) in 2006 as suitable natural ecological fertilizers for ecology farming. Provita fertilizers are made from processed pig bristles according to a special technology that removes moisture, crushes the bristles and compresses them into pellets. The fertilizer composition is $14.0 \% \mathrm{~N}_{\text {tot }}$. The fertilizer is a neutral reaction and, therefore, does not acidify the soil. Phosphorite powder is the source of $\mathrm{P}$ for plants obtained by grinding phosphorites. It contains $20 \%$ of $\mathrm{P}_{2} \mathrm{O}_{5}$. Potassium magnesia (Patentkali) is a source of $\mathrm{K}$ for plants in organic farms. Fertilizers were made from natural marine sediments. They contain $30 \% \mathrm{~K}_{2} \mathrm{O}$ (Table 1).

The studies involved growing crops in threeyear crop rotation: spring barley (Hordeum vulgare L., 2016) $\rightarrow$ potato (Solanum tuberosum L., 2017) $\rightarrow$ pea (Pisum sativum L., 2018).

All works were carried out manually. Barley grain, potato tubers and pea seeds were seedlings in the third decade of April. Barley (in 2016) and peas (in 2018) were seeded in the rate $200 \mathrm{~kg} \mathrm{ha}^{-1}$ seeds, with a $12 \mathrm{~cm}$ gap between each row. The potatoes tubers (in 2017) were planted by nine on each lysimeter plot.
Full crop yield was harvested at the end of plant maturity and manually. The crop yield samples were taken from each lysimeter plot and sent to the laboratory for analysis: barley grain and straw, potatoes tuber and pea seeds and straw. The yield of the plants was determined by weighing $\left(\mathrm{tha}^{-1}\right)$.

Two types of Haplic Luvisol were used: sandy loam and loamy. The agrochemical composition of sandy loam soils was $\mathrm{pH} 6.3, \mathrm{~N}_{\text {tot }} 0.059-0.085 \%$, $\mathrm{C}_{\text {org }} 1.45-2.05 \%, \mathrm{P}_{2} \mathrm{O}_{5}$ and $\mathrm{K}_{2} \mathrm{O} 208-244$ and $90-$ $141 \mathrm{mg} \mathrm{kg}^{-1}$. The composition of loamy sand soil was $\mathrm{pH} 5.0-5.2, \mathrm{~N}_{\text {tot }} 0.099-0.107 \%, \mathrm{C}_{\text {org }} 1.81-1.98 \%$, $\mathrm{P}_{2} \mathrm{O}_{5}$ and $\mathrm{K}_{2} \mathrm{O} 203-214$ and $152-171 \mathrm{mg} \mathrm{kg}^{-1}$.

\section{Analitical methods}

All chemical parameters were determined in the Agrochemical Research Laboratory of the Lithuanian Research Centre for Agriculture and Forestry. The soil pH was identified in the distilled water extract of $1 \mathrm{~mol} \mathrm{~L}^{-1} \mathrm{KCl}$ using the ratio 1:2.5 w:v (20 g soil/50 g water). The soil samples were shaken on an overhead shaker for $1 \mathrm{~h}$ and then left to equilibrate for $20 \mathrm{~h}$. The suspension was then agitated for $10 \mathrm{~min}$ and the $\mathrm{pH}$ was measured immediately using a pH meter WTW 315i/ SET (Weilheim, Germany). Organic carbon $\left(\mathrm{C}_{\text {org }}\right)$ content in the soil was determined by dry burn (ISO 10694:1995. Determination of organic and total carbon after the dry combustion). The mobile phosphorus $\left(\mathrm{P}_{2} \mathrm{O}_{5}\right)$ and potassium $\left(\mathrm{K}_{2} \mathrm{O}\right)$ were determined by the LVP D-07:2016 standard (Egner-Riehm-Domingo (A-L) method). Total nitrogen $\left(\mathrm{N}_{\text {tot }}\right)$ of soils was determined by the ISO 11261:1995 standard (Determination of total nitrogen - Modified Kjeldahl method).

In barley grains, straws, potatoes tuber and pea seeds with straw cattle manure, sapropel $\mathrm{N}_{\text {tot }}$ was determined by the Kjeldahl $\mathrm{N}$ distiller in accordance with the standard EN 13654-1:2012 (Soil

Table 1. Agrochemical characteristics of fertilizers

\begin{tabular}{c|c|c|c|c|c|}
\hline \multirow{2}{*}{ Fertilizer in dry matter, \% } & \multicolumn{3}{|c|}{ NPK } & \multirow{2}{*}{ Sapropel } & \multirow{2}{*}{ Manure } \\
\cline { 2 - 6 } & Provita & Phosphorite powder & Potassium magnesia & & \\
\hline Organic matter & \multicolumn{3}{|c}{} & 74.8 & 87.8 \\
\hline Total nitrogen $\left(\mathrm{N}_{\text {tot }}\right)$ & 14 & 2.0 & 1.9 \\
\hline Phosphorus $\left(\mathrm{P}_{2} \mathrm{O}_{5}\right)$ & 1.4 & 30 & 0.6 & 0.12 \\
\hline Potassium $\left(\mathrm{K}_{2} \mathrm{O}\right)$ & 0.2 & 20 & 0.18 & 2.16 \\
\hline
\end{tabular}

NPK: Provita is nitrogen source, phosphorite powder is phosphorus source, potassium magnesia (Patenkali) is potassium source. 
improvers and growing media - Determination of nitrogen. Modified Kjeldahl method), $\mathrm{P}$ and an organic fertilizer (sapropel, manure) were determined in aqua regia by the spectrometric method according to EN 13650:2001 (Soil improvers and growing media - Extraction of aqua regia soluble elements). Total $\mathrm{K}$ in crop yield and organic fertilizers (manure, sapropel) were determined according to EN 13650:2006 (Soil improvers and growing media - Extraction of aqua regia soluble elements). In filtrated water, nitrates $\left(\mathrm{NO}_{3}\right)$ were determined by the LST EN ISO-13395:2000 standard flow analysis (FIA) (Water quality. Nitrite nitrogen $\left(\mathrm{NO}_{2}^{-}\right)$, nitrate nitrogen $\left(\mathrm{NO}_{3}^{-}\right)$and their sum flow analysis (CFA and FIA) and spectrometric detection). Potassium was determined by the LST ISO 99643:1998 standard (atomic absorption spectrometry method), $\mathrm{P}$ in spectrometric, $\mathrm{K}$ according to ISO 99643:1998 (Water quality - Determination of sodium and potassium - Part 3: Determination of sodium and potassium by flame emission spectrometry) using a flame emission photometer PFP7 (Jenway, UK).

\section{Filtrated water collection and calculation}

The amount of precipitation was calculated from 1 March till 28 February next year (includes all 12 months). The amount of $\mathrm{K}$ and $\mathrm{P}$ infiltrate water was determined by taking approximately $2.5 \%$ of leached water from each of the lysimetric plots. The amount (mg) of nutrient load leached (NL) was computed as follows in Eq. (1) (Li et al., 2018):

$$
\mathrm{NL}=\mathrm{VT} \times \mathrm{C}_{\mathrm{e}} .
$$

Here $\mathrm{C}_{e}$ is the concentration $\left(\mathrm{mg} \mathrm{L}^{-1}\right)$ of any of the nutrients leached elements, and VT is the total volume of water leached per hectare in a certain period of (month, year) time (L).

The total volume (L) of water leached (VT) was determined as follows in Eq. (2):

$$
\mathrm{VT}=\frac{\mathrm{VB} \times 10000}{\mathrm{AC}} .
$$

Here VB is the volume of water pumped from the bucket lysimeter (L), and $\mathrm{AC}$ is the area of the bucket lysimeter's catch pan $\left(\mathrm{m}^{2}\right)$.

Nitrogen was expressed as the pure element $\mathrm{kg} \mathrm{ha}^{-1} \mathrm{~N}$ in the soil nutrient balance.

\section{Meteorological conditions}

For the evaluation of meteorological data and conditions, the data provided by the Vilnius Meteorological Station was used. During the experiment, the meteorological conditions were very variable: the year of excess humidity was followed by a droughty year with little rainfall.

Judging from temperature shifts during the experiment, there was a tendency for temperature to increase throughout the seasons. The periods of winter and spring 2016 demonstrated an increase in temperature compared to the climatological standard normal (SCN), which continued until mid-summer and returned to the multi-annual temperature range since mid-summer. Temperature distributions in 2017 showed lower temperatures during the summer, while all other seasons demonstrated higher temperatures compared to the multi-annual value. The higher temperature range was evident in 2018, when temperatures were well above the standard climate temperature $\left(+1.2\right.$ to $\left.4.5^{\circ} \mathrm{C}\right)$, which was particularly pronounced during the growing season and persisted until the end of autumn season $\left(+2.3\right.$ to $\left.6.7^{\circ} \mathrm{C}\right)$.

During the experiment, meteorological conditions were very uncontrasting. Significant changes in precipitation were evident: the year of excess humidity turned into a very dry year. The summer and autumn of 2017 could be marked as an extremely humid season with the highest rainfall $(377 \mathrm{~mm}$ in summer and $350 \mathrm{~mm} \mathrm{SCN} ; 271 \mathrm{~mm}$ in autumn and $158 \mathrm{~mm} \mathrm{SCN}$ ) with $35-74 \%$ more rainfall than the multi-annual precipitation value. Of greater concern was heavy rainfall in the autumn, which tended to leach unused nutrients into deeper soil layers. In 2018, there was an annual decrease in precipitation, which deceased as much as $15-45 \%$ below the multi-year standardized precipitation index for all seasons (Fig. 1). In the case of lower rainfall, a very important role was played by organic matter in soil and its content, which was capable of maintaining higher moisture content in soil needed for the main biological processes to occur.

In terms of the amount of precipitation during the experiment, we can notice an average annual increase in precipitation, and the seasonal distribution of the absolute minimum and maximum values of precipitation are more clearly observed. The most pronounced were the summer and autumn periods; during each year of the experiment 


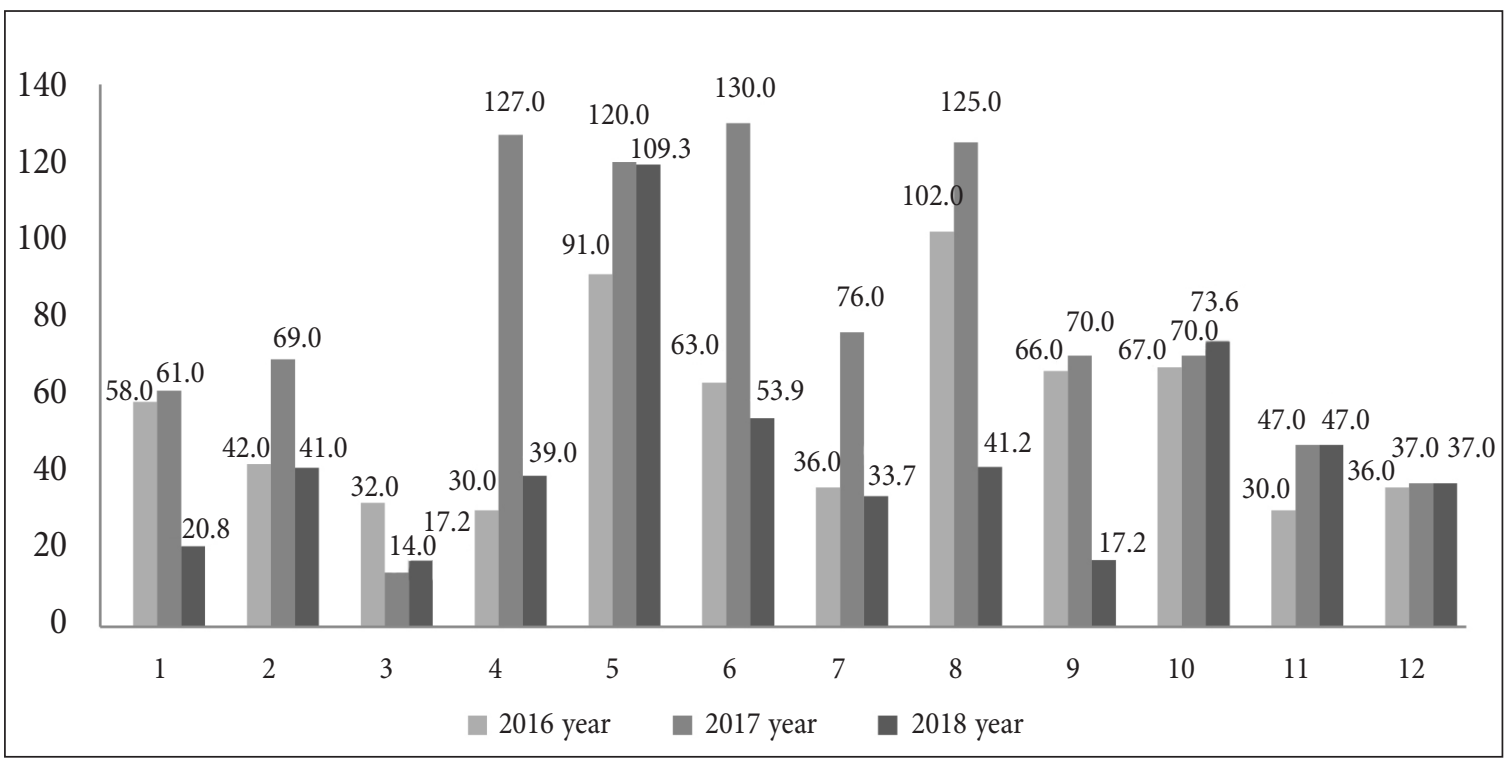

Fig. 1. Precipitation during the period of conduction of the experiment (data of the Vilnius Meteorological Station)

in those seasons, the rainfall was the highest compared to the annual rainfall.

The thermal and humidity conditions of the plant vegetation period were described using the agrometeorological indicator - G. Selianinov (1928) hydrothermal coefficient (HTC) (Fig. 2) which was calculated according to the formula in Eq. (3) (Valiukas, 2017)

$$
\mathrm{HTC}=\frac{\Sigma p}{0.1 \times \Sigma t}
$$

where $\Sigma p$ is the amount of precipitation (mm) over a period with an average temperature higher than $+10^{\circ} \mathrm{C}$, and $\Sigma t$ is the sum of active temperature $\left(>+10^{\circ} \mathrm{C}\right)$ for the same period. If $\mathrm{HTC} \geq 1.6$, moisture is too high; in the case of HTC $=1.0-1.5$, humidity is optimal; HTC $=0.9-0.8$ shows low dryness; $\mathrm{HTC}=0.7-0.6$ means middle dryness; if $\mathrm{HTC}=0.5-$ 0.4 , dryness is too high; HTC $<0.4$ shows a very severe drought. In Lithuania, the HTC is calculated from each day in a 30- or 31-day period when the average air temperature is above $+10^{\circ} \mathrm{C}$. It uses to describe the humidity condition during the active vegetation period and at the same time when we have an extreme event such as a very severe drought.

In 2016, after seeding and during the growth, it was a good time for grain growth due to low

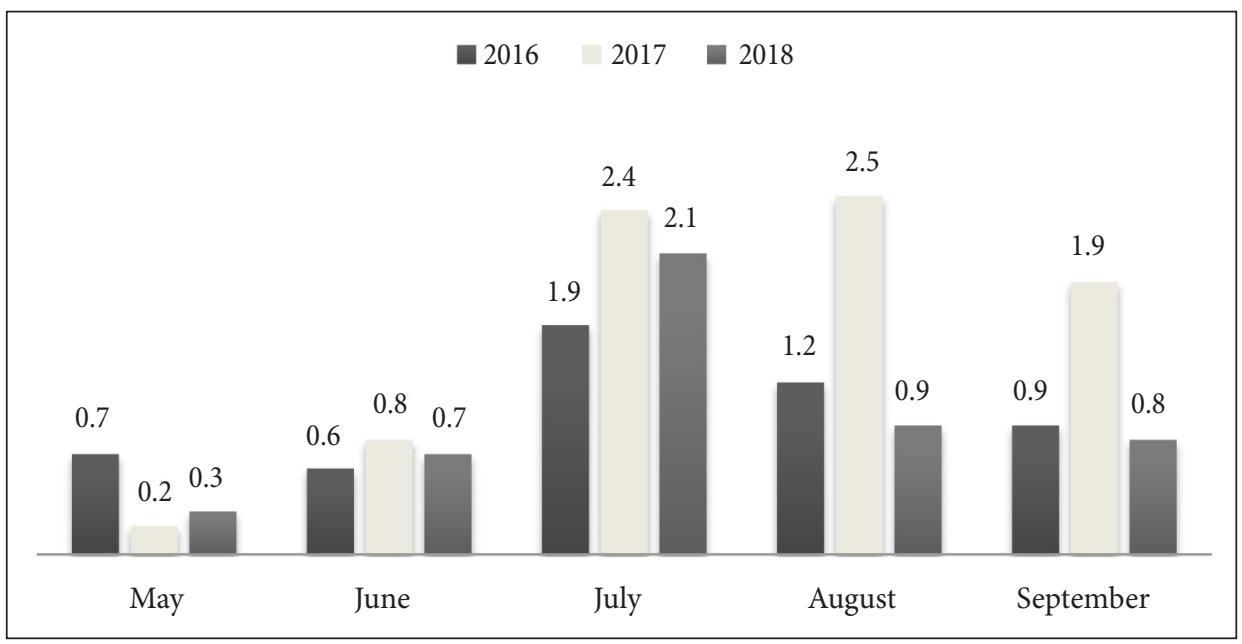

Fig. 2. Hydrothermal coefficient during the period of the experiment (data of the Vilnius Meteorological Station) 
precipitation; during the period of plant maturation (according to the values of HTC (Selianinov, 1928)), the moisture conditions were dry or optimal, which allowed cereals to grow and mature. In 2017, the vegetation period started in the first decade of May. According to HTC, the time was favourable for the sprouting of potatoe tubers; during the growth period, the conditions were unfavourable. When the leaves were growing and when it started to bloom, the moisture was very high, which affected the quality and quantity of the potato harvest. In 2018, during the period of active vegetation, pea growth and development were unfavourable, fixed a very high dryness, which gave us a very low yield supplement (Fig. 2).

The balance of nutritious elements (NPK) was calculated using the amount of nitrogen, phosphorus and potassium introduced in the soil with fertilizers and seeds, elements quantity in infiltrated water and the crop yield of barley, potatoes and peas. The data were statistically processed using the analysis of variance (ANOVA). The significant differences between the means were established by the least significant difference at a significance level of $p \leq 0.05$ (Raudonius, 2017).

\section{RESULTS AND DISCUSSION}

\section{Crops yield}

Researchers talk about fertilizer effectiveness that more depends on meteorological conditions, fertilizer compounds, soil texture and fertilization time (Janušauskatė, 2014). Inserted organic fertilizer, especially manure and sapropel in light-textured soils, is an excellent source of soil organic matter, which is not only supplement to humus in the subsoil but also protects the crop yield from unfavourable weather conditions during vegetation (Arslan et al., 2017). The significantly higher yield addition was fixed in our experiment: yields were higher in all crop growing years, as evidenced by the positive benefits of organic fertilizers discussed above. With the inserted manure fertilizer, the crop yield had a higher rate in the sandy soil (in the first year, spring barley yield was $2.8 \mathrm{t} \mathrm{ha}^{-1}$, and in the second, potato growing year it was $31.21 \mathrm{t} \mathrm{ha}^{-1}$ ), if we compare with all fertilized treatment.

In the loamy sand soil, where there is more organic matter, the higher crop yield influence mostly depends on meteorologic conditions. Despite environmental factors, the inserted manure fertilizer in the soil maintained significantly higher yields in all the experiment (barley yield $3.7 \mathrm{tha}^{-1}$, potato tubers yield $32.74 \mathrm{t} \mathrm{ha}^{-1}$, pea seeds yield $2.88 \mathrm{t} \mathrm{ha}^{-1}$ ). With other inserted fertilizers, the crop yield was slightly higher or similar to the control (without fertilizer). A significantly higher crop yield with manure was also mentioned in other research (Thomas et al., 2019).

The potato tubers yield was heavily dependent on the soil texture. Due to the extraordinary wet year, the sandy soil was not soaked and got more air if we compare it to the loamy sand soil (Table 2, Fig. 2). During the peas growing time (due to the prevailing drought) the crop yield was not very significant in the sandy loam soil, but in the loamy sand fixed the higher crop yield-growth and it mostly depends on organic content in soil and moisture retention (Oliveira et al., 2020).

Table 2. Crop yields on two different soils Haplic Luvisol using organic fertilizers

\begin{tabular}{|c|c|c|c|c|c|c|}
\hline \multirow{3}{*}{ Fertilization } & \multicolumn{6}{|c|}{ Harvest, $\mathbf{t}$ ha $^{-1}$} \\
\hline & Barley & Potato tubers & Peas & Barley & Potato tubers & Peas \\
\hline & \multicolumn{3}{|c|}{ Sandy loam } & \multicolumn{3}{|c|}{ Loamy sand } \\
\hline Control (no-fertilizer) & 1.69 & 17.49 & 1.96 & 2.01 & 23.72 & 2.66 \\
\hline NPK & 1.91 & 20.72 & 2.09 & 2.30 & 22.00 & 2.57 \\
\hline $40 \mathrm{t} \mathrm{ha}^{-1}$ sapropel & 1.28 & $24.35^{\star}$ & 2.18 & 2.20 & 23.72 & 2.71 \\
\hline $60 \mathrm{t} \mathrm{ha}^{-1}$ manure & $2.8^{*}$ & $31.21^{*}$ & 1.99 & $3.70^{*}$ & $32.74^{*}$ & $2.88^{*}$ \\
\hline $\mathrm{LSD}_{05}$ & 0.54 & 6.79 & 0.24 & 0.32 & 8.76 & 0.99 \\
\hline
\end{tabular}

NPK: Provita, phosphorite powder, potassium magnesia (Patenkali) fertilizers.

Note: ${ }^{\star}$ essentially the largest increase $\left(\mathrm{LSD}_{05}<0.05\right)$. 


\section{Nutrition circulation}

Nitrogen $(\mathrm{N})$ indicators are the key for characterizing farm performance, and appropriate management of $\mathrm{N}$ is of key importance for an organic fertilizer; it means that application of organic fertilizer has to be approximately equal to crop yields, $\mathrm{N}$ use efficiency has to increase, and $\mathrm{N}$ losses have to decrease (Zhang et al., 2018). To get a higher crop yield without loosening the soil organic matter, it is necessary to periodically input nutrients in the soil to cover the losses. A systematic monitoring of $\mathrm{N}$ balance at the farm level could contribute to understanding differences in $\mathrm{N}$ management and impacts among farms (Basak et al., 2020).
The nutrient accumulation in crop yield was determined by the size and amount of individual elements. Lisimeter plots with an inserted manure fertilizer show a quite high crop yield in all three growing years and also element accumulation in the sandy loam ranged from 117 to $200 \%$, in the loamy sand from 107 to $188 \%$. In the loamy sand soil we clearly see the positive effect of manure fertilizers in the first crop growing year, element accumulation is the highest, and in the sandy loam soil, manure fertilizer had the positive effect in the second, potato tubers growing year (Table 3). Our experiment confirms the results of Jodaugiene and other authors (2015) which state that the amount

Table 3. The amount of biogenic elements introduced into the Haplic Luvisol soils and release with harvest

\begin{tabular}{|c|c|c|c|c|c|c|}
\hline \multirow{2}{*}{$\begin{array}{c}\text { Fertilization } \\
\text { Barley }\end{array}$} & \multicolumn{3}{|c|}{ Input with fertilizers and seeds, $\mathrm{kg} \mathrm{ha}^{-1}$} & \multicolumn{3}{|c|}{ Release with harvest, $\mathrm{kg} \mathrm{ha}^{-1}$} \\
\hline & Barley & Potato tubers & Peas & Barley & Potato tubers & Peas \\
\hline \multicolumn{7}{|c|}{ Sandy loam } \\
\hline \multicolumn{7}{|c|}{ Nitrogen } \\
\hline Control (no-fertilizer) & 3.6 & 10.0 & 9.3 & 26.6 & 34.3 & 90.9 \\
\hline NPK & $53.6^{*}$ & $70.0^{*}$ & 9.3 & 32.5 & $53.8^{*}$ & 93.1 \\
\hline $40 \mathrm{t} \mathrm{ha}^{-1}$ sapropel & $174.0^{*}$ & 10.0 & 9.3 & 24.4 & $61.0^{*}$ & 101.2 \\
\hline $60 \mathrm{tha}^{-1}$ manure & $174.6^{*}$ & 10.0 & 9.3 & $44.0^{*}$ & $68.9^{*}$ & $106.1^{*}$ \\
\hline$L S D_{05}$ & 25.5 & 14.98 & 0.16 & 11.11 & 13.99 & 15.51 \\
\hline \multicolumn{7}{|c|}{ Phosphorus } \\
\hline Control (no-fertilizer) & 1.0 & 23.2 & 1.0 & 6.7 & 9.5 & 9.6 \\
\hline NPK & $51.0^{*}$ & $83.2^{*}$ & $51.0^{\star}$ & 7.4 & $11.0^{*}$ & 10.9 \\
\hline $40 \mathrm{t} \mathrm{ha}^{-1}$ sapropel & $52.0^{*}$ & 23.2 & 1.0 & 5.3 & $14.2^{*}$ & $11.7^{*}$ \\
\hline $60 \mathrm{tha}^{-1}$ manure & 11.8 & 23.2 & 1.0 & $11.4^{*}$ & $17.2^{*}$ & $12.4^{*}$ \\
\hline$L S D_{05}$ & 16.52 & 1.04 & 0.029 & 2.78 & 1.39 & 1.77 \\
\hline \multicolumn{7}{|c|}{ Potassium } \\
\hline Control (no-fertilizer) & 1.1 & 16.8 & 2.3 & 8.2 & 68.2 & 21.6 \\
\hline NPK & 51.1 & $76.8^{*}$ & $52.3^{*}$ & 8.9 & 82.8 & 25.7 \\
\hline $40 \mathrm{t} \mathrm{ha}^{-1}$ sapropel & 16.4 & 16.8 & 2.3 & 6.1 & $95.2^{*}$ & $25.9^{*}$ \\
\hline $60 \mathrm{tha}^{-1}$ manure & $195.5^{\star}$ & 16.8 & 2.3 & $12.9^{*}$ & $124.6^{*}$ & $28.4^{*}$ \\
\hline$L S D_{05}$ & 91.67 & 4.8 & 1.3 & 3.28 & 14.31 & 4.11 \\
\hline \multicolumn{7}{|c|}{ Loamy sand } \\
\hline \multicolumn{7}{|c|}{ Nitrogen } \\
\hline Control (no-fertilizer) & 3.6 & 10.0 & 9.3 & 34.9 & 55.7 & 123.4 \\
\hline NPK & $53.6^{*}$ & $70.0^{*}$ & 9.3 & $42.0^{*}$ & $69.7^{*}$ & 117.7 \\
\hline
\end{tabular}


Table 3. (Continued)

\begin{tabular}{|c|c|c|c|c|c|c|}
\hline \multirow{2}{*}{$\begin{array}{c}\text { Fertilization } \\
\text { Barley }\end{array}$} & \multicolumn{3}{|c|}{ Input with fertilizers and seeds, $\mathrm{kg} \mathrm{ha}^{-1}$} & \multicolumn{3}{|c|}{ Release with harvest, $\mathrm{kg} \mathrm{ha}^{-1}$} \\
\hline & Barley & Potato tubers & Peas & Barley & Potato tubers & Peas \\
\hline $60 \mathrm{tha}^{-1}$ manure & $174.6^{*}$ & 10.0 & 9.3 & $65.5^{*}$ & $75.0^{*}$ & 130.8 \\
\hline$L S D_{05}$ & 25.55 & 14.98 & 0.16 & 5.89 & 12.18 & 12.33 \\
\hline \multicolumn{7}{|c|}{ Phosphorus } \\
\hline Control (no-fertilizer) & 1.0 & 23.2 & 1.0 & 10.5 & 14.2 & 13.8 \\
\hline NPK & $51.0^{*}$ & $83.2^{*}$ & $50.0^{*}$ & 11.3 & 18.0 & 13.4 \\
\hline $40 \mathrm{t} \mathrm{ha}^{-1}$ sapropel & $52.1^{\star}$ & 23.2 & 1.0 & 11.4 & $21.4^{*}$ & 13.9 \\
\hline $60 \mathrm{tha}^{-1}$ manure & 11.8 & 23.2 & 1.0 & $17.9^{*}$ & $23.2^{*}$ & 14.7 \\
\hline$L S D_{05}$ & 16.52 & 1.04 & 0.029 & 2.05 & 4.86 & 1.71 \\
\hline \multicolumn{7}{|c|}{ Potassium } \\
\hline Control (no-fertilizer) & 1.1 & 16.8 & 2.3 & 10.7 & 102.1 & 33.2 \\
\hline NPK & 51.1 & $76.8^{\star}$ & $52.3^{\star}$ & 12.5 & $128.6^{*}$ & 31.4 \\
\hline $40 \mathrm{t} \mathrm{ha}^{-1}$ sapropel & 16.4 & 16.8 & 2.3 & 12.3 & $151.2^{\star}$ & 33.2 \\
\hline $60 \mathrm{tha}^{-1}$ manure & $195.5^{\star}$ & 16.8 & 2.3 & $19.4^{*}$ & $167.8^{*}$ & 35.4 \\
\hline$L S D_{05}$ & 91.67 & 4.8 & 1.3 & 2.15 & 26.27 & 3.74 \\
\hline
\end{tabular}

NPK: Provita, phosphorite powder, potassium magnesia (Patenkali) fertilizers.

Note: ${ }^{\star}$ essentially the largest increase $\left(\mathrm{LSD}_{05}<0.05\right)$.

of $\mathrm{N}, \mathrm{P}$ and $\mathrm{K}$ accumulated by agricultural plants is inversely proportional to the yield (Table 3 ).

Following the trends of food elements leaching, the infiltration of precipitation depends not only on the amount of precipitation and the cultivated agricultural crops but also on the soil texture (Owuor et al., 2016; Karmakar et al., 2016). The light texture soil, which has a low organic matter, leached needed elements into groundwater, because of the huge amount of precipitation (Fig. 1).

All inserted ecological-organic fertilizers decreased nitrogen leaching losses in the sandy loam soil in the first and second years after application. Compared with all inserted fertilizers, we can see that the organic sapropel fertilizer slightly increases the nitrogen leaching in the first year $\left(13.2 \mathrm{~kg} \mathrm{ha}^{-1}\right)$, and in the second and third years we noticed more leaching losses with the inserted manure fertilizer (16.3 $\mathrm{kg} \mathrm{ha}^{-1}$ in the second year, $8.06 \mathrm{~kg} \mathrm{ha}^{-1}$ in the third year) (Table 4$)$.

In the first year, in the loamy sand the inserted organic sapropel fertilizer increased the nitrogen leaching losses $\left(10.1 \mathrm{~kg} \mathrm{ha}^{-1}\right)$. In the second experiment year, the manure slightly increased the nitrogen leaching (15.9 $\left.\mathrm{kg} \mathrm{ha}^{-1}\right)$, if we compare with all inserted fertilizers (Table 4).
Some researchers have found that $\mathrm{N}$ leaching loss can range from 12 to $75 \mathrm{~kg} \mathrm{~N} \mathrm{ha}^{-1}$, depending on crop types, cropping system (irrigated or dryland), soil texture, $\mathrm{N}$ fertilization rate and climatic conditions (Ross et al., 2008). In this case, we can strongly say that nitrogen leaching losses depend on soil texture, and an inserted fertilizer has a good influence on nitrogen losses amount per year (Table 4). In total, in all three years, we got less nitrogen leaching losses with the inserted organic sapropel fertilizer in both types of soil $\left(32.2 \mathrm{~kg} \mathrm{~N} \mathrm{ha}^{-1}\right.$ in sandy loam, $24.8 \mathrm{~kg} \mathrm{~N} \mathrm{ha}^{-1}$ in loamy sand).

The Ministry of Agriculture ordered by the Agrochemical Research Laboratory of Lithuanian Research Centre for Agriculture and Forestry published a report about the 2016-2017 year: nonfrozen ground in winter and moisture in summer, which can encourage the main nutrient loss because of the heavy precipitation (https://zum.lrv.lt). Phosphorus leaching levels are not very significant in the sandy loam and loamy sand soils. Phosphorus was located mainly in subsoil - in a biologically active layer profile. The $\mathrm{P}$ penetration into the deeper layers of the soil is generally low. The P significant leaching depends on soil acidity and structure composition (Lynch, Wojciechowski, 2015). 
Table 4. The main nutrient elements leaching in Haplic Luvisol soils

\begin{tabular}{|c|c|c|c|c|c|c|c|c|}
\hline \multirow{3}{*}{ Fertilization } & \multicolumn{8}{|c|}{ Leached elements, $\mathrm{kg} \mathrm{ha}^{-1}$} \\
\hline & Barley & Potato & Peas & Total & Barley & Potato & Peas & Total \\
\hline & \multicolumn{4}{|c|}{ Sandy loam } & \multicolumn{4}{|c|}{ Loamy sand } \\
\hline & \multicolumn{8}{|c|}{ Nitrogen } \\
\hline Control (no-fertilizer) & 13.7 & 19.6 & 4.1 & 37.2 & 12.4 & 20.4 & 3.1 & 35.8 \\
\hline NPK & $10.2^{\star *}$ & $15.8^{\star *}$ & $6.6^{*}$ & 32.5 & $7.3^{* *}$ & $15.4^{\star *}$ & $4.1^{\star}$ & $26.8^{* *}$ \\
\hline $40 \mathrm{t} \mathrm{ha}^{-1}$ sapropel & 13.2 & $13.5^{\star}$ & 5.5 & 32.2 & $10.1^{* *}$ & $11.3^{* *}$ & 3.5 & $24.8^{* *}$ \\
\hline $60 \mathrm{tha}^{-1}$ manure & 11.1 & 16.3 & $8.1^{*}$ & 35.4 & $7.0^{* *}$ & $15.9^{* *}$ & $2.4^{* *}$ & $25.3^{* *}$ \\
\hline \multirow[t]{2}{*}{$L S D_{05}$} & 2.11 & 1.99 & 1.04 & 4.45 & 1.77 & 1.67 & 0.60 & 4.87 \\
\hline & \multicolumn{8}{|c|}{ Phosphorus } \\
\hline Control (no-fertilizer) & 0.18 & 0.26 & 0.06 & 0.5 & 0.13 & 0.24 & 0.06 & 0.43 \\
\hline NPK & 0.18 & 0.26 & 0.09 & 0.53 & $0.75^{*}$ & $0.28^{*}$ & $0.14^{*}$ & $1.17^{\star}$ \\
\hline $40 \mathrm{tha}^{-1}$ sapropel & $0.14^{* *}$ & $0.23^{* *}$ & $0.08^{* *}$ & 0.45 & 0.28 & $0.26^{*}$ & 0.09 & 0.63 \\
\hline $60 \mathrm{tha}^{-1}$ manure & $0.11^{\star \star}$ & $0.24^{\star *}$ & $0.07^{\star *}$ & 0.42 & 0.31 & 0.25 & 0.08 & 0.64 \\
\hline \multirow[t]{2}{*}{$L S D_{05}$} & 0.034 & 0.012 & 0.011 & 0.41 & 0.46 & 0.011 & 0.08 & 0.28 \\
\hline & \multicolumn{8}{|c|}{ Potassium } \\
\hline Control (no-fertilizer) & 14.69 & 19.93 & 10.27 & 44.88 & 16.75 & 20.31 & 5.16 & 42.22 \\
\hline NPK & $19.03^{*}$ & $27.22^{*}$ & 10.12 & $56.37^{\star}$ & $19.27^{\star}$ & $22.54^{\star}$ & $7.04^{*}$ & $49.52^{*}$ \\
\hline $40 \mathrm{t} \mathrm{ha}^{-1}$ sapropel & $21.34^{*}$ & $22.98^{\star}$ & $11.79^{*}$ & $56.11^{\star}$ & $17.47^{\star}$ & $25.23^{*}$ & $7.47^{*}$ & $50.12^{*}$ \\
\hline $60 \mathrm{tha}^{-1}$ manure & $17.56^{*}$ & 20.53 & $9.51^{* *}$ & 47.59 & 17.09 & $22.27^{\star}$ & $6.13^{*}$ & $45.48^{\star}$ \\
\hline$L S D_{05}$ & 0.97 & 1.86 & 0.62 & 4.03 & 0.712 & 0.81 & 0.35 & 2.07 \\
\hline
\end{tabular}

NPK: Provita, phosphorite powder, potassium magnesia (Patenkali) fertilizers.

Note: ${ }^{\star}$ essentially the largest increase $\left(\mathrm{LSD}_{05}\right)$;

** essentially the largest decrease $\left(\operatorname{LSD}_{01}\right)$.

Scientists have found that nitrate anions increase $\mathrm{K}$ leaching from the soil when using higher $\mathrm{N}$ rates, especially with manure fertilizers. However, this statement was not proved in our experiment (Filho et al., 2014; Timsina, 2018). Timsina (2018) declares that only nutrients that are not used in plant growth are leached out from agroecosystems. Even in unfavourable weather, the effect of temperature extremes and heavy rain conditions during the active vegetation time may increase the nutrient loss (Barlow et al., 2015; Hatfield, Prueger, 2015).

\section{NPK balance}

The balance of plant nutrients mainly depends on the fertility of agricultural plants, which in the sustainable farming system is lower than in the intensive one. It also depends on the soil composition and weather conditions during the vegetation period (Rajawat, 2019; Zhang et al., 2018).
Estimation of nutrients material uptake in threeyear crop rotation shows a quite high $\mathrm{K}$ nutrient uptake with the inserted manure in the sandy loam soil $-516 \%$, and in the loamy sand soil it is $695 \%$. In the loamy sand soil, a high N uptake with NPK fertilizer (159\%) was fixed, and after application of manure we clearly see a good accumulation of $\mathrm{P}$ nutrient (115\%). Higher crop yields also result in more nutrient losses that do not return to the soil (Wood et al., 2018; Pekarskas, 2012). Inserted organic fertilizers not only provide nutrients for agricultural crops during the vegetation time, but also the supplement to the soil humus (Mieldažys et al., 2019; H-Kattoof et al., 2019). The small K amount of sapropel fertilizer added did not ensure a positive balance, which may, in the short future, only mean decreasing of the soil organic matter.

The highest $\mathrm{P}$ consumption was calculated with the inserted manure fertilizer in the sandy loam soil, up to $115 \%$, and in the loamy sand soil it was 
$157 \%$. Phosphorus is a very essential element for plants as it helps the healthy development of the root system and also hastens maturity. It is necessary for harvest formation and its deficiency reduces the crop yield (Abbas et al., 2018; Siddiqui et al., 2015). The lowest amount of $\mathrm{P}$ was with the manure fertilizer, and it resulted in a negative balance in the sandy loam $\left(-5.4 \mathrm{~kg} \mathrm{ha}^{-1}\right)$ and loamy sand soils $\left(-20.4 \mathrm{~kg} \mathrm{ha}^{-1}\right)$. No significant use of phosphorus is visible in NPK fertilizers every year and in total (16\% in sandy loam, $23 \%$ in loamy sand), so an attempt can be made to reduce the amount of phosphorus added before seeding (Table 5). Performance of the phosphorus source of

Table 5. The balance of basic nutrients (NPK) in differently fertilized Haplic Luvisol

\begin{tabular}{|c|c|c|c|c|}
\hline Fertilization & $\begin{array}{c}\text { Input with } \\
\text { fertilizers and } \\
\text { seeds, } \mathrm{kg} \mathrm{ha}^{-1}\end{array}$ & $\begin{array}{c}\text { Taken with harvest } \\
\text { and leached with } \\
\text { rainfall }\end{array}$ & $\begin{array}{c}\text { Balance after } \\
\text { three-year crop } \\
\text { rotation }\end{array}$ & $\begin{array}{l}\text { Nutrients taken, } \\
\%(\text { taken } \times 100) / \\
\text { inserted }\end{array}$ \\
\hline \multicolumn{5}{|c|}{ Sandy loam } \\
\hline \multicolumn{5}{|c|}{ Nitrogen } \\
\hline Control (no-fertilizer) & 22.9 & 189 & -166.1 & 825 \\
\hline $\mathrm{NPK}$ & 132.9 & 211.9 & -79 & 159 \\
\hline $40 \mathrm{t} \mathrm{ha}^{-1}$ sapropel & 193.3 & 218.8 & -25.5 & 113 \\
\hline $60 \mathrm{t} \mathrm{ha}^{-1}$ manure & 193.9 & 254.4 & -61.4 & 131 \\
\hline \multicolumn{5}{|c|}{ Phosphorus } \\
\hline Control (no-fertilizer) & 25.2 & 26.3 & -1.1 & 104 \\
\hline NPK & 185.2 & 29.8 & 155.4 & 16 \\
\hline $40 \mathrm{t} \mathrm{ha}^{-1}$ sapropel & 76.2 & 31.7 & 44.5 & 42 \\
\hline $60 \mathrm{t} \mathrm{ha}^{-1}$ manure & 36.0 & 41.4 & -5.4 & 115 \\
\hline \multicolumn{5}{|c|}{ Potassium } \\
\hline Control (no-fertilizer) & 20.2 & 142.9 & -122.7 & 707 \\
\hline NPK & 180.2 & 155.1 & 25.1 & 86 \\
\hline $40 \mathrm{t} \mathrm{ha}^{-1}$ sapropel & 35.5 & 183.3 & -147.8 & 516 \\
\hline $60 \mathrm{t} \mathrm{ha}^{-1}$ manure & 214.6 & 213.49 & -1.11 & 99 \\
\hline \multicolumn{5}{|c|}{ Loamy sand } \\
\hline \multicolumn{5}{|c|}{ Nitrogen } \\
\hline Control (no-fertilizer) & 22.9 & 294.8 & -227 & 1087 \\
\hline NPK & 132.9 & 255.8 & -122.9 & 192 \\
\hline $40 \mathrm{t} \mathrm{ha}^{-1}$ sapropel & 193.3 & 267.4 & -74.1 & 138 \\
\hline $60 \mathrm{t} \mathrm{ha}^{-1}$ manure & 193.9 & 296.6 & -102.7 & 153 \\
\hline \multicolumn{5}{|c|}{ Phosphorus } \\
\hline Control (no-fertilizer) & 25.2 & 38.9 & -13.7 & 154 \\
\hline NPK & 184.2 & 43.9 & 140.3 & 23 \\
\hline $40 \mathrm{t} \mathrm{ha}^{-1}$ sapropel & 76.2 & 47.3 & 29.1 & 62 \\
\hline $60 \mathrm{t} \mathrm{ha}^{-1}$ manure & 36.0 & 56.4 & -20.4 & 157 \\
\hline \multicolumn{5}{|c|}{ Potassium } \\
\hline Control (no-fertilizer) & 20.2 & 188.2 & -168.5 & 932 \\
\hline NPK & 180.2 & 222.1 & -41.8 & 123 \\
\hline $40 \mathrm{t} \mathrm{ha}^{-1}$ sapropel & 35.5 & 246.9 & -211.3 & 695 \\
\hline $60 \mathrm{t} \mathrm{ha}^{-1}$ manure & 214.6 & 268.1 & -53.5 & 125 \\
\hline
\end{tabular}

NPK: Provita, phosphorite powder, potassium magnesia (Patenkali) fertilizers. 
phosphorite powder lasts for a dozen years (Pekarskas, 2012; Helal et al., 2019).

The results show quite high $\mathrm{N}$ uptake rates of the inserted NPK organic fertilizer: N 159\% in sandy loam soil and N 192\% in loamy sand soil. Provita as an organic fertilizer is very effective in fertilizing soils but in the future a little more $\mathrm{N}$ nutrient may be necessary to avoid the negative balance in soil.

The inserted amount of $\mathrm{N}$ with manure fertilizers in the sandy loam and loamy sand soils ensured the positive balance, after three-year crop rotation (Table 5). The cattle manure tendency of a prolonged effect on agricultural crop harvest may range from 3 to 4 or from 7 to 8 years and besides does contribute to the amount of humus formation in the subsoil. When organic fertilizers are applied to the soil, there is a high probability of leaching during the heavy precipitation (Tampere et al., 2014; Bley et al., 2017) and it partly confirms the tendencies of nutrient leaching, published by other scientists (Table 5).

\section{CONCLUSIONS}

1. The three-year balance results of $\mathrm{P}$ and $\mathrm{K} \mathrm{nu}-$ trients in the sandy loam show that the NPK and sapropel fertilization ensures positive nutrients for all treatment time. In the loamy sand soil with the before-mentioned fertilizers, the result was only $P$ positive balance.

2. With the NPK fertilizer we got the highest nitrogen consumption in crop production as a result of a negative balance in both types of soil. All other remaining fertilizers got less $\mathrm{N}$ to consume but the result was the same which, in the short future, only mean the decreasing of soil organic matter.

3. In light texture soils such as sandy loam and loamy sand, sapropel fertilization showed the positive results of less $\mathrm{N}$ leaching losses content. Based on these results, sapropel fertilizing in the light texture soils with a poor hummus amount from less $\mathrm{N}$ losses may be recommended.

Received 30 April 2020

Accepted 2 October 2020

\section{REFERENCES}

1. Abbas W., Anwar S., Akram W., Shah W. A., Islam M., Iqbal B., Ikramullah, Shehryar khan,
Khattak W. A., Hussain S., Alamzeb M., Iqbal A. 2018. Response of Barley varieties to Phosphorus and Sulphur levels. Pure and Applied Biology. P. 247-254.

2. Ahlvik L., Ekholm P., Hyytiäinen K., Pitkänen H. 2014. An economic-ecological model to evaluate impacts of nutrient abatement in the Baltic Sea. Environmental Modelling and Software. Vol. 55. P. 164-175.

3. Arslan A., Belotti F., Lipper L. 2017. Smallholder productivity and weather shocks: adoption and impact of widely promoted agricultural practices in Tanzania. Food Policy, Elsevier. Vol. 69(C). P. 68-81.

4. Barlow K. M., Christy B. P., Leary G. J., Riffkin P. A., Nuttall J. G. 2015. Simulating the impact of extreme heat and frost events on wheat crop production: review. Field Crops Research. Vol. 171. P. 109-119.

5. Basak B. B., Maity A., Biswas D. R. 2020. Cycling of Natural Sources of Phosphorus and Potassium for Environmental Sustainability. Geophysical Monograph Series. P. 285-299.

6. Bley H., Gianello C., Santos L. S., Selau L. P. R. 2017. Nutrient release, plant nutrition, and potassium leaching from polymer-coated fertilizer. Revista Brasileira De Ciência Do Solo. Vol. 41. P. e0160142.

7. Delin S., Stenberg M. 2014. Effect of nitrogen fertilisation on nitrate leaching in relation to grain yield response on loamy sand in Sweden. European Journal of Agronomy. Vol. 52(Part B). P. 291-296.

8. Diacono M. A., Montemurro F. 2015. Review effectiveness of organic wastes as fertilizers and amendments in salt-affected soils. Agriculture. Vol. 5. P. 221-230.

9. Doltra J., Jørgen O. 2013. The role of catch crop in the ecological intensification of spring cereals in organic farming under Nordic climate. European Journal of Agronomy. Vol. 44. P. 98-108.

10. Duran B. E. L., Duncan D. S., Oates L. G., Ducharik C. J., Jackson R. D. 2016. Nitrogen fertilization effects on productivity and nitrogen loss in three grass-based perennial bioenergy cropping systems. PLoS One. Vol. 11(3). P. e0151919.

11. El-Ramady H. R., Alshaal T. A., Amer M., DomokosSzabolcsy É., Elhawat N., Prokisch J., Fári M. 2014. Soil quality and plant nutrition. Sustainable Agriculture Reviews. Vol. 14. P. 345-447.

12. Fess T. L., Benedito V. A. 2018. Organic versus conventional cropping sustainability: a comparative system analysis. Sustainability. Vol. 10. P. 272.

13. Filho O., Guedes da Silva A. P., Giarola N. F. B., Tormena C. A. 2014. Least-limiting water range of the soil seedbed submitted to mechanical and biological chiselling under no-till. Soil Research. Vol. 52. P. 521-532.

14. Hatfield J. L., Prueger J. H. 2015. Temperature extremes: Effect on plant growth and development. Weather and Climate Extremes. Vol. 10. P. 4-10. 
15. Hellal F., El-Sayed S., Zewainy R., Amer A. 2019. Importance of phosphate pock application for sustaining agricultural production in Egypt. Bulletin of the National Research Centre. Vol. 43. P. 1-11.

16. H-Kattoof S., El-Gamry A. M., Fouda K. F., Abo ElEzz S. F. 2019. Organic fertilizers derived from farm by-products for sustainable agriculture: a review. Journal of Soil Sciences and Agricultural Engineering. Vol. 10. No. 12. P. 815-819.

17. Islam M. N., Rahman M. M., Mianmm J. A., Khan M. H., Barua R. 2015. Leaching losses of nitrogen, phosphorus and potassium from the sandy loam soil of old Brahmaputra floodplain (AEZ9) under continuous standing water condition. Bangladesh Journal of Agricultural Research. Vol. 39. No. 3. P. 437-446.

18. Janušauskaitė D. 2014. Analysis of grain yield and its components in spring triticale under different $\mathrm{N}$ fertilization regimes. Žemdirbystè-Agriculture. Vol. 101. No. 4. P. 381-388.

19. Jodaugienė D., Bogužas V., Mikučionienė R., Auželienè I., Zemeckis R. 2015. Effect of crop rotation and preceding crop on nutrient content taken out with cereal yield. Žemés ūkio mokslai. Vol. 22. No. 1. P. 26-35 (in Lithuanian).

20. Jones J. W., Antle J. M., Basso B., Boote K. J., Conant R. T., Foster I., Godfray H., Herrero M., Howitt R. E., Janssen S., Keating B. A., Munoz-Carpena R., Porter C. H., Rosenzweig C., Wheeler T. R. 2017. Toward a new generation of agricultural system data, models, and knowledge products: State of agricultural systems science. Agricultural Systems. Vol. 155. P. 269-288.

21. Karmakar R., Das I., Dutta D., Rakshit A. 2016. Potential effects of climate change on soil properties: a review. Science International. Vol. 4. No. 2. P. 51-73.

22. Khan M. N., Mobin M., Abbas Z. K., Alamri S. A. 2018. Fertilizers and their contaminants in soils, surface and groundwater. In: The Encyclopedia of the Anthropocene. Vol. 5. Oxford: Elsevier. P. 225-240.

23. Li Y., Li J., Gao L., Tian Y. 2018. Irrigation has more influence than fertilization on leaching water quality and the potential environmental risk in excessively fertilized vegetable soils. PLOS One. Vol. 13. No. 9. P. e0204570.

24. Lynch J. P., Wojciechowski T. 2015. Opportunities and challenges in the subsoil: pathways to deeper rooted crops. Journal of Experimental Botany. Vol. 66. No. 8. P. 2199-2210.

25. Mieldažys R., Jotautienė E., Jasinskas A., Pekarskas J., Zinkevičienè R. 2019. Investigation of physical-mechanical properties and impact on soil of granulated manure compost fertilizers. Journal of Environmental Engineering and Landscape Management. Vol. 27. P. 153-162.

26. Oliveira F. C. C., Fereira G. W. D., Souza J. L. S., Vieira M. E. O., Pedrotti A. 2020. Soil physical prop- erties and soil organic carbon content in northeast Brazil: long-term tillage systems effects. Scientia Agricola. Vol. 77. No. 4. P. e20180166.

27. Owuor S. O., Butterbach-Bahl K., Guzha A. C., Rufino M. C., Pelster D. E., Díaz-Pinés E., Breuer L. 2016. Groundwater recharge rates and surface runoff response to land use and land cover changes in semi-arid environments. Ecological Processes. Vol. 5. No. 1. P. 16.

28. Pekarskas J. 2012. Effect of growth activator Penergetic-p on organically grown spring wheat. Žemés ūkio mokslai. Vol. 19. No. 3. P. 151-160 (in Lithuanian).

29. Rajawat M. S. 2019. Plant nutrients and it's impact. Acta Scientific Agriculture. Vol. 3. No. 6. P. 31-33.

30. Raudonius S. 2017. Application of statistics in plant and crop research: important issues. ŽemdirbysteAgriculture. V. 104. No. 4. P. 377-382.

31. Ross S. M., Izaurralde R. C., Janzen H. H., Robertson J. A., McGill W. B. 2008. The nitrogen balance of three long-term agroecosystems on a boreal soil in western Canada. Agriculture, Ecosystems \& Environment. Vol. 127. P. 241-25031.

32. Selianinov G. T. 1928. On agricultural climate valuation. Transactions on Agricultural Meteorology. Vol. 20. P. 164-177 (in Russian).

33. Siddiqui S. N., Umar S., Husen A., Iqbal M. 2015. Effect of phosphorus on plant growth and nutrient accumulation in a high and a low zinc-accumulating chickpea genotypes. Annals of Phytomedicine. Vol. 4. P. 102-105.

34. Tampere M., Kauer K., Keres I., Loit E., Selge A., Viiralt R., Raave H. 2014. Effects of sward botanical composition on nitrogen and potassium leaching in cut grassland. Žemdirbysté-Agriculture. Vol. 101. No. 4. P. 389-394.

35. Thomas C. L., Acquah G. E., Whitmore A. P., McGrath S. P., Haefele S. M. 2019. The effect of different organic fertilizers on yield and soil and crop nutrient concentrations. Agronomy. Vol. 9. No. 12. P. 776 .

36. Timmusk S., Behers L., Muthoni J., Muraya A., Aronsson A. C. 2017. Perspectives and challenges of microbial application for crop improvement. Frontiers in Plant Science. Vol. 8. No. 49. P. 1-18.

37. Timsina J. 2018. Can organic sources of nutrients increase crop yields to meet global food demand? Agronomy. Vol. 8. No. 10. P. 214-234.

38. Valiukas D. 2017. Identification of extreme droughts and dry periods in Lithuania in 1961-2015 using Selianinov's hydrothermal coefficient. Geologija. Geografija. Vol. 3. No. 3. P. 101-113 (in Lithuanian).

39. Wood S., Baudron F. 2018. Soil organic matter underlies crop nutritional quality and productivity in smallholder agriculture. Agriculture Ecosystems and Environment. Vol. 266. P. 100-108.

40. World Reference Base for Soil Resources. 2014. World Soil Resources Reports No. 106. FAO. P. 187-189. 
41. Zhang W., Wang Ch., Dong M., Jin Sh., Li H. 2018. Dynamics of soil fertility and maize growth with lower environment impacts depending on a combination of organic and mineral fertilizer. Journal of Soil Science and Plant Nutrition. Vol. 18. No. 2. P. 556-575.

42. Zorb C., Senbayram M., Peiter E. 2014. Potassium in agriculture - status and perspectives. Journal of Plant Physiology. Vol. 171. No. 9. P. 656-669.

\section{Auksė Burakova, Eugenija Bakšienė, Almantas Ražukas}

\section{AUGALŲ MINERALINĖS MITYBOS \\ PAGRINDINIŲ ELEMENTŲ BALANSAS \\ NAUDOJANT EKOLOGINES TRĄŠAS}

\section{Santrauka}

Tyrimai atlikti stacionariuose cilindro formos lizimetruose, kurie pripildyti Rytų Lietuvos regionui būdingu dirvožemiu: paprastojo išplautžemio priesmèliu ir paprastojo išplautžemio lengvu priemoliu (Haplic Luvisol). Eksperimento metu buvo stebima pagrindinių maisto elementu (azoto $(\mathrm{N})$, fosforo (P) ir kalio (K)) apykaita naudojant ekologines trąšas, kad būtų ịvertintas jų efektyvumas ir tinkamumas lengvos struktūros dirvožemiuose ir augalų derliuje. Nustatyta, kad per trejus eksperimento metus paprastojo išplautžemio priesmèlyje ir paprastojo išplautžemio lengvame priemolyje $\mathrm{N}$ balansas buvo neigiamas, bet patręšus sapropeliu rezultatai tapo teigiami - mažiausias išplautas $\mathrm{N}$ kiekis, palyginti su kitomis ekologinėmis organinėmis trąšomis. P teigiamo elementų balanso neužtikrino kraikiniu galvijų méšlu patręštuose laukeliuose ir abiejų tipų dirvožemiuose dèl mažo su trąšomis ịterpto jo kiekio bei didelio sukaupto kiekio derliuje. Kiekvienais metais ịterpiamas kalio kiekis su NPK trą̌somis užtikrino teigiamą elemento balansą tik paprastojo išplautžemio priesmèlyje.

Raktažodžiai: derlius, išsiplovimo nuostoliai, NPK balansas, organinès trąšos 